\title{
Influence of feed form and energy concentration of the rearing phase diets on productivity, digestive tract development and body measurements of brown-egg laying hens fed diets varying in energy concentration from 17 to 46 wk of age
}

\author{
B. Saldaña ${ }^{a}$, C.E. Gewehr ${ }^{a}{ }^{1}$, P. Guzmán ${ }^{a}$, J. García ${ }^{\mathrm{b}}$, G.G. Mateos ${ }^{\mathrm{a}, *}$ \\ a Departamento de Producción Agraria, Universidad Politécnica de Madrid, 28040 Madrid, Spain \\ b Camar Agroalimentaria, S.L., 45214 Toledo, Spain
}

\section{A R T I C L E I N F O}

\section{Article history:}

Received 9 March 2016

Received in revised form 25 August 2016

Accepted 27 August 2016

\section{Keywords:}

Body weight gain

Crumbles

Egg quality

Energy concentration

Gastrointestinal tract traits

\begin{abstract}
A B S T R A C T
The influence of feed form and energy content of the rearing phase diets on hen productivity, gastrointestinal tract (GIT) traits and body measurements was studied in brown-egg laying hens fed diets differing in energy concentration from 17 to $46 \mathrm{wk}$ of age. The experiment was completely randomized with 12 treatments arranged as a $(2 \times 3) \times 2$ factorial with two feed forms (mash vs. crumbles) and three $\mathrm{AME}_{\mathrm{n}}$ concentrations of the rearing phase diets (low, medium and high) and two $\mathrm{AME}_{\mathrm{n}}$ concentrations ( $11.10 \mathrm{vs} .11 .52 \mathrm{MJ} / \mathrm{kg}$ ) of the laying phase diets. The $\mathrm{AME}_{\mathrm{n}}$ of the rearing phase diets differed in $0.42 \mathrm{MJ} / \mathrm{kg}$ in all three periods (1-5 wk, 5-10 wk and 10-17 wk of age). Hen productivity was determined from 17 to 46 wk and GIT and body traits were measured at $46 \mathrm{wk}$ of age. The characteristics of the rearing phase diets did not affect any of the production, GIT traits or body measurements studied during the laying phase, except body weight gain (BWG) from 17 to $46 \mathrm{wk}$ of age that was higher $(\mathrm{P}<0.01)$ in hens that were fed mash during the rearing phase than in hens that were fed crumbles. An increase in the energy content of the laying phase diet from 11.10 to $11.52 \mathrm{MJ} \mathrm{AME}_{\mathrm{n}} / \mathrm{kg}$ reduced feed intake $(\mathrm{P}<0.001)$ and improved feed conversion ratio $(\mathrm{P}<0.001)$ from 17 to $46 \mathrm{wk}$ and reduced gizzard contents $(\mathrm{P}<0.01)$ at $46 \mathrm{wk}$ of age but did not affect any of the other production trait studied. The characteristics of the rearing and laying hen diets did not affect any of the GIT traits or body measurements at $46 \mathrm{wk}$ of age. Body weight of the hens was positively $(\mathrm{P}<0.001)$ related with body length, body mass index, tarsus length and tarsus diameter at this age. The data indicate that neither feed form nor energy concentration of the rearing phase diets affected subsequent hen performance. An increase in the $\mathrm{AME}_{\mathrm{n}}$ content of the layer diet from 11.10 to $11.52 \mathrm{MJ} / \mathrm{kg}$ decreased feed intake and improved feed conversion ratio but did not affect hen production or egg quality.
\end{abstract}

(c) 2016 Elsevier B.V. All rights reserved.

\footnotetext{
Abbreviations: $\mathrm{AME}_{\mathrm{n}}$, apparent metabolisable energy, corrected for nitrogen; ADFI, average daily feed intake; BMI, body mass index; BW, body weight; BWG, body weight gain; FCR, feed conversion ratio; GIT, gastrointestinal tract; HE, high energy; LE, low energy; LNA, linoleic acid; ME, medium energy.

* Corresponding author.

E-mail address: gonzalo.gmateos@upm.es (G.G. Mateos).

1 Current address: Departamento de Produção Animal, Universidade do Estado de Santa Catarina, 88520-000 Lages, Brazil.
} 


\section{Introduction}

Light hens produce less eggs at the start of the laying period and lay smaller eggs during the laying cycle than heavy hens (Leeson et al., 1997; Pérez-Bonilla et al., 2012a), resulting in a reduction in flock profitability (Pérez-Bonilla et al., 2012b). Two potential nutritional strategies used for increasing the initial body weight (BW) of the hens at the onset of egg production are the feeding of crumbled diets (Frikha et al., 2009a; Gous and Morris, 2001; Saldaña et al., 2015a) and the use of high energy diets (Frikha et al., 2009b; Saldaña et al., 2015b) during the rearing phase. However, Nir et al. (1994) and Serrano et al. (2013) in broilers and Guzmán et al. (2015a) and Saldaña et al. (2015a, b) in pullets, have shown that feeding crumbles or pellets reduced the relative weight $(\mathrm{g} / \mathrm{kg} \mathrm{BW})$ of the gizzard and the development of the gastrointestinal tract (GIT) as compared with feeding mash. Also, when the energy concentration of the diet increases, fiber content decreases, which also reduces GIT development (González-Alvarado et al., 2007; Jiménez-Moreno et al., 2009a; Sacranie et al., 2012). A poorly developed GIT affects feed intake and might result in pullets not consuming enough energy to meet their requirements for optimal egg production during the first weeks of the laying phase (Pérez-Bonilla et al., 2012b; Guzmán et al., 2016). Consequently, the effects of greater BW but reduced GIT capacity at $17 \mathrm{wk}$ of age, because of feeding a high energy diet in crumble form during the rearing phase, might counteract each other and the final effect on egg production and egg size might depend on other nutritional and management practices.

Laying hens eat to satisfy their energy requirements and therefore, voluntary feed intake decreases as the energy content of the diet increases (Leeson et al., 1997). However, low energy diets might result in hens consuming less feed than required to maximize egg production, especially in light birds at the onset of egg production (Pérez-Bonilla et al., 2012a). Moreover, high energy diets contain usually increased amounts of supplemental fat which may result in improved feed efficiency and an increase in egg size (Mateos and Sell, 1981; Grobas et al., 1999a).

Body measurements, such as body length, body mass index (BMI; g BW/body length ${ }^{2}$ ) and tarsus length and diameter, are useful criteria to predict body size and future production of laying hens (Ojedapo et al., 2012; Guzmán et al., 2016). However, the information available on the effects of the characteristics of the rearing and laying hen diets on these variables are limited.

The hypothesis of this research was that pullets fed high energy diets in crumble form during the rearing phase could have greater BW but less developed GIT at the start of the laying phase than pullets fed low energy diets in mash form, which could result in similar productivity during the laying phase. Also, feeding low energy diets during the laying phase could result in reduced egg mass production and egg weight, effects that could be more pronounced in those hens that were lighter or had a poor developed GIT at the onset of the egg production cycle. This research evaluated the effects of feed form and energy concentration of the rearing phase diets on performance, egg quality, digestive tract traits and body measurements of hens fed diets differing in energy concentration from 17 to $46 \mathrm{wk}$ of age.

\section{Materials and methods}

The procedures described in this research were approved by the Animal Ethics Committee of the Universidad Politécnica de Madrid and were in compliance with the Spanish guidelines for the care and use of animals in research (Boletín Oficial del Estado, 2007).

\subsection{Husbandry, diets and experiment design}

Details on bird management and feeding program from hatching to $17 \mathrm{wk}$ of age have been reported by Saldaña et al. (2015b). Briefly, one-day-old Lohmann Brown Classic pullets were placed in an environmentally controlled barn and allotted in groups of 50 into 36 cages with similar initial average BW. The feeding program consisted of three periods $(0-5 \mathrm{wk}, 5-10$ wk and 10-17 wk of age) in which the energy concentrations of the diets varied in $0.42 \mathrm{MJ} / \mathrm{kg}$ (from 11.93 to $12.77,11.30$ to 12.14 and 11.10 to $11.94 \mathrm{MJ} \mathrm{AME}_{\mathrm{n}} / \mathrm{kg}$ for the three feeding periods, respectively). During the rearing phase, the treatments consisted in six diets arranged as a $2 \times 3$ factorial with two feed forms (crumbles vs. mash) and three energy concentrations (LE, low energy, ME, medium energy; HE, high energy). Each treatment was replicated six times. All diets had similar amino acids and nutrient content per unit of energy. The ingredient composition and the calculated and determined nutritive value of the rearing phase diets are shown in Table 1.

At $17 \mathrm{wk}$ of age, pullets from each of the six previous rearing treatments (LE, ME and HE in mash or crumble form) were pooled and then, distributed in groups of nine birds into ten enriched cages $(40 \mathrm{~cm} \times 80 \mathrm{~cm} \times 68 \mathrm{~cm}$; Facco S.A., Padova, Italy). Half of the cages of each of the six groups received a low energy layer diet $(11.10 \mathrm{MJ} \mathrm{AME} / \mathrm{kg}$ ) and the other half a high energy layer diet $\left(11.52 \mathrm{MJ} \mathrm{AME}_{\mathrm{n}} / \mathrm{kg}\right.$ ). The two layer diets had the same nutritive value per unit of energy (FEDNA, 2010). Feed in mash form and water were provided for ad libitum consumption. The light program consisted of $15 \mathrm{~h}$ for the first week of the experiment and $16 \mathrm{~h}$ thereafter. Room temperature was recorded daily throughout the experiment with a maximum of $27 \pm 3^{\circ} \mathrm{C}$ (July, second period of the experiment) and a minimum of $23 \pm 3^{\circ} \mathrm{C}$ (January, last period of the experiment). The experiment lasted for seven periods of four week each, with the exception of the first period that lasted five wk (17-22 wk). The ingredient composition and the calculated and determined analyses of the laying phase diets are shown in Table 2. 
Table 1

Ingredient composition and calculated and determined analyses ( $\mathrm{g} / \mathrm{kg}$ as fed basis) of the rearing phase diets.

\begin{tabular}{|c|c|c|c|c|c|c|c|c|c|}
\hline & \multicolumn{3}{|c|}{0 to 5 week } & \multicolumn{3}{|c|}{5 to 10 week } & \multicolumn{3}{|c|}{10 to 17 week } \\
\hline & $\mathrm{LE}^{\mathrm{a}}$ & $\mathrm{ME}^{\mathrm{b}}$ & $\mathrm{HE}^{\mathrm{c}}$ & LE & ME & $\mathrm{HE}$ & LE & ME & $\mathrm{HE}$ \\
\hline \multicolumn{10}{|l|}{ Ingredient } \\
\hline Maize & 350 & 350 & 350 & 350 & 350 & 350 & 200 & 200 & 200 \\
\hline Wheat & 192 & 174 & 157 & - & 50 & 100 & 315 & 357 & 400 \\
\hline Barley & - & - & - & 280 & 233 & 185 & 100 & 103 & 105 \\
\hline Soybean meal, $455 \mathrm{~g} \mathrm{CP} / \mathrm{kg}$ & 333 & 367 & 401 & 220 & 265 & 310 & 90 & 130 & 170 \\
\hline Sunflower meal, $320 \mathrm{~g} \mathrm{CP} / \mathrm{kg}$ & - & - & - & 100 & 50 & - & - & - & - \\
\hline Sunflower meal, $280 \mathrm{~g} \mathrm{CP} / \mathrm{kg}$ & 60 & 30 & - & - & - & - & 150 & 115 & 80 \\
\hline Bran & - & - & - & - & - & - & 100 & 50 & - \\
\hline Soy oil & 27.1 & 40.8 & 53.7 & 10 & 15.0 & 20 & 8.5 & 10.3 & 12 \\
\hline Dicalcium phosphate & 20.7 & 20.7 & 20.6 & 15.3 & 15.7 & 16 & 15 & 15.1 & 15.3 \\
\hline Calcium carbonate & 10.4 & 10.5 & 10.6 & 16.4 & 14.0 & 11.6 & 14.4 & 12.9 & 11.6 \\
\hline Sodium chloride & 3.5 & 3.5 & 3.5 & 3.5 & 3.4 & 3.3 & 3.5 & 3.5 & 3.5 \\
\hline$D L$-methionine, $990 \mathrm{~g} / \mathrm{kg}$ & 1.3 & 1.5 & 1.6 & 1.1 & 1.3 & 1.5 & 0.5 & 0.6 & 0.6 \\
\hline L-threonine, $980 \mathrm{~g} / \mathrm{kg}$ & - & - & - & 0.8 & 0.7 & 0.6 & - & - & - \\
\hline$L$-lysine $\cdot \mathrm{HCl}, 780 \mathrm{~g} / \mathrm{kg}$ & - & - & - & 0.9 & 0.5 & - & 1.1 & 0.6 & - \\
\hline Premix $^{\mathrm{d}}$ & 2.0 & 2.0 & 2.0 & 2.0 & 2.0 & 2.0 & 2.0 & 2.0 & 2.0 \\
\hline \multicolumn{10}{|l|}{ Calculated analyses $^{\mathrm{e}}$} \\
\hline $\mathrm{AME}_{\mathrm{n}}(\mathrm{MJ} / \mathrm{kg})$ & 11.93 & 12.35 & 12.77 & 11.30 & 11.72 & 12.14 & 11.10 & 11.52 & 11.94 \\
\hline Neutral detergent fiber & 111 & 100 & 89 & 136 & 120 & 104 & 180 & 155 & 130 \\
\hline Crude protein & 217 & 222 & 227 & 190 & 194 & 199 & 161 & 167 & 172 \\
\hline \multicolumn{10}{|l|}{ Digestible amino acid } \\
\hline Lys & 9.7 & 10.2 & 10.8 & 8.4 & 8.7 & 9.0 & 6.1 & 6.3 & 6.5 \\
\hline Met + Cys & 7.2 & 7.4 & 7.6 & 6.5 & 6.7 & 6.9 & 5.3 & 5.5 & 5.6 \\
\hline Thr & 6.8 & 7.1 & 7.3 & 6.7 & 6.8 & 6.8 & 4.5 & 4.8 & 5.0 \\
\hline Calcium & 11.0 & 11.0 & 11.0 & 10.3 & 9.4 & 8.5 & 10.7 & 10.2 & 9.7 \\
\hline Digestible phosphorus & 4.4 & 4.3 & 4.3 & 4.3 & 4.4 & 4.4 & 3.7 & 3.6 & 3.5 \\
\hline \multicolumn{10}{|l|}{ Determined analyses ${ }^{\mathrm{f}}$} \\
\hline Dry matter & 911 & 907 & 909 & 904 & 911 & 919 & 914 & 917 & 913 \\
\hline $\mathrm{GE}(\mathrm{MJ} / \mathrm{kg})$ & 17.42 & 17.51 & 17.94 & 16.59 & 16.73 & 16.93 & 16.81 & 16.57 & 16.75 \\
\hline Ether extract & 56 & 64 & 75 & 35 & 42 & 46 & 30 & 30 & 31 \\
\hline Crude fiber & 41 & 38 & 32 & 62 & 59 & 54 & 66 & 58 & 52 \\
\hline Crude proteing & 213 & 225 & 235 & 183 & 182 & 186 & 161 & 164 & 164 \\
\hline Lys & 11.3 & - & 12.1 & 9.9 & - & 10.5 & 6.9 & - & 7.6 \\
\hline Met + Cys & 8.4 & - & 9.0 & 7.3 & - & 7.9 & 6.4 & - & 6.5 \\
\hline Thr & 8.3 & - & 8.7 & 7.7 & - & 8.1 & 5.2 & - & 60 \\
\hline Total ash & 59 & - & 59 & 50 & - & 62 & 57 & - & 53 \\
\hline
\end{tabular}

a $11.93,11.30$ and $11.10 \mathrm{MJ} \mathrm{AME} / \mathrm{kg}$ from 0 to $5 \mathrm{wk}, 5$ to $10 \mathrm{wk}$ and 10 to $17 \mathrm{wk}$ of age, respectively.

b $12.35,11.72$ and $11.52 \mathrm{MJ} \mathrm{AME}_{\mathrm{n}} / \mathrm{kg}$ from 0 to $5 \mathrm{wk}, 5$ to $10 \mathrm{wk}$ and 10 to $17 \mathrm{wk}$ of age, respectively.

c $12.77,12.14$ and $11.94 \mathrm{MJ} \mathrm{AME} / \mathrm{kg}$ from 0 to $5 \mathrm{wk}, 5$ to $10 \mathrm{wk}$ and 10 to $17 \mathrm{wk}$ of age, respectively.

d Supplied per kilogram of diet: vitamin A (trans-retinyl acetate), 10,000 IU; vitamin $\mathrm{D}_{3}$ (cholecalciferol), 3500 IU; vitamin E (all-rac-tocopherol-acetate), 35 mg; vitamin $B_{1}, 2$ mg; vitamin $B_{2}, 8$ mg; vitamin $B_{6}, 4$ mg; vitamin $B_{12}$ (cyanocobalamin), 0.025 mg; vitamin $K_{3}$ (bisulphatemenadione complex), 3 mg; choline (choline chloride), $270 \mathrm{mg}$; nicotinic acid, $60 \mathrm{mg}$; pantothenic acid (D-calcium pantothenate), $15 \mathrm{mg}$; folic acid, $1.5 \mathrm{mg}$; D-biotin, $0.15 \mathrm{mg}$; zinc (ZnO), $90 \mathrm{mg}$; manganese (MnO), $75 \mathrm{mg}$; iron $\left(\mathrm{FeCO}_{3}\right), 60 \mathrm{mg}$; copper $\left(\mathrm{CuSO}_{4} \bullet 5 \mathrm{H}_{2} \mathrm{O}\right), 8 \mathrm{mg}$; iodine $(\mathrm{KI}), 2 \mathrm{mg} ;$ selenium $(\mathrm{Na} 2 \mathrm{SeO})_{3}, 0.3 \mathrm{mg}$; Roxazyme, $200 \mathrm{mg}$ [1600 U of endo-1,4- $\beta$-glucanase (EC 3.2.1.4), $3600 \mathrm{U}$ of endo-1,3 (4)- $\beta$-glucanase (EC 3.2.1.6) and 5200 U of endo-1,4- $\beta$-xylanase (EC 3.2.1.8)] supplied by DSM S.A., Madrid, Spain; and Natuphos 5000 [300 FTU/kg 6-phytase (EC 3.1.3.26), 60 mg, supplied by Basf Española S.A, Tarragona, Spain].

e According to FEDNA (2010).

f Data correspond to the average of the mash and crumble diets. The differences in values between the mash and crumble diets were within acceptable ranges.

g Total amino acids was not determined for the ME diets.

The experiment was conducted as a completely randomized design with 12 treatments in a factorial arrangement with two feed forms (mash vs. crumbles) and three energy concentrations (LE, ME and HE) during the rearing phase and two diets that differed in $\mathrm{AME}_{\mathrm{n}}$ content (low and high) during the laying phase. Each of the 12 treatments was replicated five times and the experimental unit was an enriched cage with nine hens.

\subsection{Measurements}

Feed disappearance and egg production by replicate were recorded by period as well as for the entire experiment. Hens were weighed by replicate at the beginning of the experiment and at the end of each of the seven experimental periods. Any mortality was recorded and weighed as produced. Egg production data are presented as number of eggs per hen per day. Egg size was estimated by weighing all eggs produced the last two days of each week. The average value of the four weeks (or five wk for the first period) was used to estimate egg weight by period and used for further analysis. From these data, average daily feed intake (ADFI), egg production, egg weight, egg mass, feed conversion ratio (FCR) per kilogram of eggs and per dozen of eggs and BW gain (BWG) were calculated by period and for the entire experiment. 
Table 2

Ingredient composition and calculated and determined analyses ( $\mathrm{g} / \mathrm{kg}$ as fed basis) of the laying phase diets.

\begin{tabular}{|c|c|c|}
\hline & $11.10 \mathrm{MJ} / \mathrm{kg}$ & $11.52 \mathrm{MJ} / \mathrm{kg}$ \\
\hline \multicolumn{3}{|l|}{ Ingredient } \\
\hline Wheat & 400 & 400 \\
\hline Maize & 200 & 170 \\
\hline Soybean meal, $470 \mathrm{~g} \mathrm{CP} / \mathrm{kg}$ & 171 & 180 \\
\hline Sunflower meal, $340 \mathrm{~g} \mathrm{CP} / \mathrm{kg}$ & 103 & 110 \\
\hline Sunflower oil soapstocks & 14.5 & 33.9 \\
\hline Dicalcium phosphate & 10.8 & 11.8 \\
\hline Calcium carbonate & 82.4 & 85.0 \\
\hline Sodium chloride & 2.8 & 3.0 \\
\hline$D L$-methionine, $990 \mathrm{~g} / \mathrm{kg}$ & 1.1 & 1.3 \\
\hline Sepiolite $^{\mathrm{a}}$ & 9.4 & - \\
\hline Vitamin and mineral premix ${ }^{\mathrm{b}}$ & 5.0 & 5.0 \\
\hline \multicolumn{3}{|l|}{ Calculated analysis ${ }^{\mathrm{c}}$} \\
\hline DM & 894 & 898 \\
\hline $\mathrm{AME}_{\mathrm{n}}, \mathrm{MJ} / \mathrm{kg}$ & 11.10 & 11.52 \\
\hline $\mathrm{CP}$ & 174 & 180 \\
\hline Crude fiber & 44 & 46 \\
\hline Neutral detergent fiber & 111 & 114 \\
\hline \multicolumn{3}{|l|}{ Digestible amino acid } \\
\hline Lys & 6.8 & 7.1 \\
\hline Met & 3.7 & 4.0 \\
\hline Met + Cys & 6.3 & 6.6 \\
\hline Thr & 5.3 & 5.5 \\
\hline Trp & 1.8 & 1.9 \\
\hline Calcium & 37.5 & 38.5 \\
\hline Total phosphorus & 6.1 & 6.4 \\
\hline Digestible phosphorus & 3.5 & 3.7 \\
\hline \multicolumn{3}{|l|}{ Determined analyses $^{\mathrm{d}}$} \\
\hline Gross energy MJ/kg & 16.11 & 16.21 \\
\hline DM & 900 & 895 \\
\hline $\mathrm{CP}$ & 182 & 185 \\
\hline \multicolumn{3}{|l|}{ Total amino acid } \\
\hline Lys & 8.2 & 8.4 \\
\hline Met & 4.1 & 4.3 \\
\hline Met + Cys & 7.4 & 7.5 \\
\hline Thr & 6.6 & 6.7 \\
\hline Trp & 2.1 & 2.2 \\
\hline Ether extract & 54 & 68 \\
\hline Linoleic acid & 19 & 27 \\
\hline Ash & 130 & 133 \\
\hline $\mathrm{GMD} \pm \mathrm{GSD}^{\mathrm{e}}$ & $1112 \pm 2.06$ & $1132 \pm 2.10$ \\
\hline
\end{tabular}

a A complex magnesium silicate clay incorporated as an inert material.

b Provided the following (per kilogram of diet): vitamin A (trans-retinyl acetate), 10,000 IU; vitamin D3 (cholecalciferol), 3750 IU; vitamin E (dl- $\alpha$ tocopheryl acetate), $10 \mathrm{mg}$; vitamin B1, $1.3 \mathrm{mg}$; vitamin B2, $5 \mathrm{mg}$; vitamin B6, $2 \mathrm{mg}$; vitamin B12 (cyanocobalamin), $13 \mathrm{mg}$; niacin, $25 \mathrm{mg}$; pantothenic acid (d-calcium pantothenate), $10 \mathrm{mg}$; folic acid, $1 \mathrm{mg}$; biotin, $13 \mathrm{mcg}$; choline (choline chloride), $250 \mathrm{mg}$; manganese (MnO), $88 \mathrm{mg} ; \mathrm{zinc}$ ( $\mathrm{ZnO}$ ), $63 \mathrm{mg}$; iron $\left(\mathrm{FeSO}_{4} \cdot \mathrm{H}_{2} \mathrm{O}\right), 38 \mathrm{mg}$; copper $\left(\mathrm{CuSO}_{4} \cdot 5 \mathrm{H}_{2} \mathrm{O}\right), 8 \mathrm{mg}$; iodine $\left[\mathrm{Ca}\left(\mathrm{IO}_{3}\right)_{2}\right], 0.7 \mathrm{mg}$; selenium $\left(\mathrm{Na}_{2} \mathrm{SeO}_{3}\right), 0.3 \mathrm{mg}$; Roxazyme, $200 \mathrm{mg}[1600 \mathrm{U}$ of endo-1,4- $\beta$ glucanase (EC 3.2.1.4), 3600 U of endo-1,3 (4)- $\beta$-glucanase (EC 3.2.1.6) and $5200 \mathrm{U}$ of endo-1,4- $\beta$-xylanase (EC 3.2.1.8)] supplied by DSM S.A., Madrid, Spain; Natuphos 5000 (300 FTU/kg supplied by BASF Española, S.A., Tarragona, Spain), 60 mg.

c According to FEDNA (2010).

d Determined analyses were analyzed in duplicate except geometric mean diameter that was determined in triplicate.

e Geometric mean diameter \pm Log normal SD.

All eggs produced throughout the experiment were classified and the number of dirty, broken and shell-less eggs, was recorded by replicate. An egg was considered as dirty when a spot of any kind or size was detected on the shell. Other egg quality traits, including yolk and shell color, Haugh units, shell strength and shell thickness, were measured in 12 eggs collected randomly from each replicate the last two days of each of the seven experimental periods. Haugh units and yolk color (Roche color fan) were measured in fresh eggs using a multitester equipment (QCMSystem, Technical Services and Supplies, Dunnington, York, UK) as indicated by Pérez-Bonilla et al. (2012a). Shell color was evaluated using a Minolta colorimeter (Chroma Meter Model CR-200, Minolta Corp., Ramsey, NJ) and the Hunter color values [L* (lightness), $\mathrm{a}^{*}$ (green to red) and $\mathrm{b}^{*}$ (blue to yellow)] were recorded. Egg shell strength, expressed in $\mathrm{g} / \mathrm{cm}^{2}$, was evaluated using a press meter (Egg Force Reader, SANOVO Technology A/S, Odense, Denmark) as indicated by Safaa et al. (2008). Shell thickness was measured at the two pole ends and at the middle section of the egg shell with a digital micrometer (model IT-014UT, Mitotuyo, Kawasaki, Japan) and the average of the three measurements of each of the 12 eggs was used for further analyses. 
At 46 wk of age, after the corresponding hen production control, two hens per replicate were randomly selected, weighed individually and euthanized by $\mathrm{CO}_{2}$ inhalation. The full digestive tract, from the post-crop esophagus to the cloaca, including digesta content, liver, pancreas and spleen, was removed and weighed. Then, the full proventriculus and gizzard, and the liver were excised and weighed. In addition, the gizzard was emptied from any digest content, cleaned, dried with desiccant paper and weighed again. The weight of the organs was expressed relative $(\mathrm{g} / \mathrm{kg})$ to live BW and the weight of the gizzard contents was expressed as a percentage of the full organ weight. Gizzard pH was measured in situ in duplicate in all these hens using a digital pH meter fitted with a fine tip glass electrode (model 507, Crison Instruments S.A., Barcelona, Spain) as indicated by Jiménez-Moreno et al. (2009b). The length of the duodenum (from the gizzard to the pancreo-biliary ducts), jejunum (from the pancreo-biliary ducts to the Meckel's diverticulum), ileum (from the Meckel's diverticulum to the ileocecal valve) and of the two ceca (from the ostium to the tip of the right and left ceca) was also measured. The length of the small intestine was determined by adding the length of the duodenum, jejunum and ileum. In addition, the length of the hens from the tip of the beak to the end of the longest phalanx was measured on a glass surface at 17 and 46 wk of age in extended birds, using a flexible tape with a precision of one $\mathrm{mm}$. From these measurements, BMI was estimated by dividing the BW $(\mathrm{g})$ of the hen by the corporal length ${ }^{2}(\mathrm{~cm})$ as indicated by Mendes et al. (2007). Also, the length and diameter of the tarsus of these hens were measured with the aid of a digital caliper and expressed as $\mathrm{cm}$ per $\mathrm{kg}$ of BW. The average value of the traits measured in the two hens was used for further statistical analysis.

\subsection{Laboratory analysis}

Representative samples of the laying hen diets were ground in a laboratory mill (Retsch Model Z-I, Stuttgart, Germany) equipped with a one-mm screen and analyzed for moisture by the oven-drying (method 930.15), total ash in a muffle furnace (method 942.05) and nitrogen by Dumas (method 968.06) using a Leco analyzer (Model FP-528, Leco Corp., St. Joseph, MI) as indicated by AOAC International (2005). Ether extract was determined after $3 \mathrm{~N} \mathrm{HCl}$ acid hydrolysis (Boletín Oficial del Estado, 1995) and gross energy was determined using an adiabatic bomb calorimeter (model 1356, Parr Instrument Company, Moline, IL, USA). The amino acid content was analyzed by chromatography (Hewlett-Packard 1100, Waldbronn, Germany) in samples ground at $0.5 \mathrm{~mm}$ as described by De Coca-Sinova et al. (2008) and the linoleic acid (LNA) content as indicated by Grobas et al. (1999a). Particle size distribution and mean particle size of the diets, expressed as geometric mean diameter, were determined in a $100 \mathrm{~g}$ sample using a shaker (Retsch, Stuttgart, Germany) provided with eight sieves ranging in mesh from 5000 to $40 \mu \mathrm{m}$ as indicated by the ASAE (1995).

\subsection{Statistical analysis}

The normal distribution of residuals and variance homogeneity of the data were tested by the UNIVARIATE procedure and the Levene's Test, respectively (SAS Institute, 2004). The effects of dietary treatment (feed form and AMEn content of the rearing phase diet and AMEn content of the laying phase diet) and their interactions on hen production were analyzed as repeated measures using the MIXED. Data on GIT development and body measurements were analyzed using the GLM procedure of SAS (SAS Institute, 2004). When significant differences among treatments were detected, means were separated using the Tukey test. In addition, the Pearson correlation analyses (SAS Institute, 2004) was used to study the relation between $\mathrm{BW}$ of the hens and body length, BMI and tarsus length and diameter at $46 \mathrm{wk}$ of age. Differences were considered significant at $\mathrm{P}<0.05$.

\section{Results}

\subsection{Hen performance and egg quality}

Details on pullet performance from hatching to $17 \mathrm{wk}$ of age have been reported by Saldaña et al. (2015b). Briefly, feeding crumbles increased ADFI (52.9 vs. $49.7 \mathrm{~g} ; \mathrm{P}<0.001)$ and BWG (12.7 vs. $11.6 \mathrm{~g} ; \mathrm{P}<0.001)$ and improved FCR (4.18 vs. 4.27; $\mathrm{P}<0.001$ ) of the pullets. Consequently, BW at $17 \mathrm{wk}$ of age was higher in pullets that were fed crumbles than in pullets that were fed mash (1554 vs. $1432 \mathrm{~g}$; $\mathrm{P}<0.001)$. An increase in the energy content of the rearing diets decreased ADFI linearly $(\mathrm{P}<0.001)$ and improved FCR quadratically $(\mathrm{P}<0.01)$ but energy intake $\left(\mathrm{KJ} \mathrm{AME}_{\mathrm{n}} / \mathrm{d}\right)$ was not affected.

Mortality during the laying phase was $1.8 \%$ and was not related to treatment (data not shown). No interactions among main effects on hen productivity were detected and therefore, only main effects are presented (Table 3). From 17-46 wk of age, type of diet fed during the rearing phase did not affect any of the productive traits studied, except BWG that was higher (386 vs. $282 \mathrm{~g} ; \mathrm{P}<0.001$ ) for hens that were fed mash during the rearing phase than for hens that were fed crumbles (Figs. 1 and 2). Most of the differences in BWG between the two groups of hens occurred from 17 to 22 wk of age and in fact, no significant differences were detected after this age. As a result, BW of the hens at 46 wk of age was similar for all hens, irrespective of the feed form or energy concentration of the rearing phase diets.

An increase in the energy content of the laying phase diets reduced ADFI (113 vs. $109 \mathrm{~g} ; \mathrm{P}<0.001$ ) and improved FCR per $\mathrm{kg}$ (1.98 vs. 1.92; $\mathrm{P}<0.001)$ and per dozen (1.44 vs. $1.41 ; \mathrm{P}<0.005)$ of eggs but did not affect any of the other traits studied. The effects of energy concentration of the diet on hen productivity by period are shown in Fig. 3. Egg quality (percentage of 
Table 3

Effects of feed form and energy concentration of the rearing diets and energy concentration ( $\left.\mathrm{AME} \mathrm{E}_{\mathrm{n}} / \mathrm{kg}\right)$ of the laying hen diet on hen production from 17 to 46 wk of age.

\begin{tabular}{|c|c|c|c|c|c|c|c|c|c|}
\hline & \multirow[t]{2}{*}{ Egg production $^{\mathrm{c}}$} & \multirow[t]{2}{*}{ ADFI (g/hen) } & \multirow[t]{2}{*}{ Egg weight (g) } & \multirow[t]{2}{*}{ Egg mass (g/d) } & \multicolumn{2}{|l|}{ FCR } & \multicolumn{2}{|l|}{$\mathrm{BW}(\mathrm{g})$} & \multirow[t]{2}{*}{ BW gain (g) } \\
\hline & & & & & $(\mathrm{kg}: \mathrm{kg})$ & (kg:dozen) & 17 wk & $46 \mathrm{wk}$ & \\
\hline \multicolumn{10}{|c|}{ Feed form, rearing phase } \\
\hline Mash & 0.936 & 111 & 61.0 & 57.0 & 1.95 & 1.43 & $1432^{\mathrm{b}}$ & 1816 & $386^{a}$ \\
\hline Crumbles & 0.930 & 110 & 60.9 & 56.6 & 1.95 & 1.42 & $1554^{\mathrm{a}}$ & 1836 & $282^{\mathrm{b}}$ \\
\hline \multicolumn{10}{|c|}{ Energy level, rearing phase } \\
\hline $\mathrm{LE}^{\mathrm{d}}$ & 0.942 & 111 & 61.1 & 57.2 & 1.94 & 1.42 & 1486 & 1833 & 347 \\
\hline $\mathrm{ME}^{\mathrm{e}}$ & 0.927 & 111 & 60.8 & 56.3 & 1.96 & 1.43 & 1487 & 1802 & 316 \\
\hline $\mathrm{HE}^{\mathrm{f}}$ & 0.930 & 110 & 61.0 & 56.7 & 1.96 & 1.43 & 1506 & 1842 & 340 \\
\hline \multicolumn{10}{|c|}{ Energy level, laying phase } \\
\hline Low $^{\text {g }}$ & 0.938 & $113^{a}$ & 60.9 & 57.0 & $1.98^{\mathrm{a}}$ & $1.44^{\mathrm{a}}$ & 1.494 & 1815 & 321 \\
\hline High $^{\text {h }}$ & 0.928 & $109^{\mathrm{b}}$ & 61.0 & 56.6 & $1.92^{\mathrm{b}}$ & $1.41^{\mathrm{b}}$ & 1492 & 1837 & 347 \\
\hline $\mathrm{SD}^{\mathrm{i}}$ & 0.0298 & 3.07 & 0.95 & 1.55 & 0.047 & 0.047 & 37.6 & 60.4 & 58.5 \\
\hline \multicolumn{10}{|l|}{ P-value } \\
\hline \multicolumn{10}{|l|}{ Rearing phase } \\
\hline Feed form & 0.380 & 0.423 & 0.738 & 0.325 & 0.721 & 0.840 & 0.001 & 0.210 & 0.002 \\
\hline Energy level & 0.296 & 0.613 & 0.743 & 0.109 & 0.199 & 0.532 & 0.174 & 0.104 & 0.338 \\
\hline \multicolumn{10}{|l|}{ Laying phase } \\
\hline Energy level & 0.198 & 0.001 & 0.797 & 0.476 & 0.001 & 0.005 & 0.848 & 0.174 & 0.102 \\
\hline
\end{tabular}

a Means with different superscript within each main effect are significantly different $(\mathrm{P}<0.05)$.

b Means with different superscript within each main effect are significantly different $(\mathrm{P}<0.05)$.

c Eggs/hen per day.

d $11.93,11.30$ and $11.10 \mathrm{MJ} \mathrm{AME}_{\mathrm{n}} / \mathrm{kg}$ from 0 to $5 \mathrm{wk}, 5$ to $10 \mathrm{wk}$ and 10 to $17 \mathrm{wk}$ of age, respectively.

e $12.35,11.72$ and $11.52 \mathrm{MJ} \mathrm{AME} / \mathrm{kg}$ from 0 to $5 \mathrm{wk}, 5$ to $10 \mathrm{wk}$ and 10 to $17 \mathrm{wk}$ of age, respectively.

f $12.77,12.14$ and $11.94 \mathrm{MJ} \mathrm{AME} / \mathrm{kg}$ from 0 to $5 \mathrm{wk}, 5$ to $10 \mathrm{wk}$ and 10 to $17 \mathrm{wk}$ of age, respectively.

g $11.10 \mathrm{MJ} \mathrm{AME} / \mathrm{kg}$.

h $11.52 \mathrm{MJ} \mathrm{AME}_{\mathrm{n}} / \mathrm{kg}$.

i 30 replicates for feed form in the rearing phase, 20 replicates for energy level in the rearing phase and 30 replicates for energy level in the laying phase.

$\mathrm{j}$ The interactions among main effects were not significant $(\mathrm{P}>0.05)$.

dirty eggs, Haugh units, yolk color, shell color, shell strength and shell thickness) was not affected by the type of diet used during the rearing or the laying phases (Table 4).

\subsection{Digestive traits and body measurements}

Details on the effects of the characteristics of the rearing phase diet on GIT traits and body measurements of the pullets have been reported elsewhere (Saldaña et al., 2015b). Briefly, the relative weight of the GIT and the gizzard and gizzard digesta content was lower $(\mathrm{P}<0.05$ to $\mathrm{P}<0.001)$ and gizzard $\mathrm{pH}$ was higher $(\mathrm{P}<0.05$ to $\mathrm{P}<0.001)$ in pullets fed crumbles than in pullets fed mash at all ages $(5,10$ and 17 wk of age). Body and tarsus length was shorter $(\mathrm{P}<0.01)$ at all ages in pullets fed crumbles than in pullets fed mash. Energy concentration of the diet did not affect any of the GIT traits or body measurements evaluated.

During the laying period, no interactions between the characteristics of the rearing phase diets and the energy content of the laying phase diets were detected for any of the traits studied and therefore, only main effects are presented (Tables 5 and 6). At 46 wk of age, gizzard content was higher in hens fed the low energy layer diet than in hens fed the high energy layer diet ( 281 vs. $261 \mathrm{~g} / \mathrm{kg}$; P < 0.01). The RW of the full proventriculus, full and empty gizzard and the liver, as well as the $\mathrm{pH}$ of the gizzard contents and the length of the small intestine and cecum, were not affected by the energy content of the layer diet. Similarly, body length, BMI and tarsus length and diameter of the hens were not affected by dietary treatment (Table 7). Hen BW showed a positive correlation $(\mathrm{P}<0.001)$ with body length, BMI and tarsus length and diameter $($ Table 8$)$.

\section{Discussion}

\subsection{Hen performance}

\subsubsection{Rearing phase diets}

In general, pullets that are heavier at $17 \mathrm{wk}$ of age anticipate sexual maturity and egg production and lay larger eggs than pullets that are lighter (Renema et al., 1999a; Pérez-Bonilla et al., 2012b). In this respect, Summers et al. (1987) and Renema et al. (1999b) reported a positive relation between BW of the hens and the maturation of the reproductive traits and the onset of egg production. In the current research, hens that received crumbles during the rearing phase were heavier at 17 wk of age and started egg production sooner (data not shown) and laid more eggs (0.913 vs. 0.898 ) that were heavier (56.2 vs. $55.4 \mathrm{~g}$ ) from 17 to $22 \mathrm{wk}$ of age than hens that were fed mash, although the differences did not reach significance. Moreover, 
Table 4

Effects of feed form and energy concentration of the rearing diets and energy concentration ( $\mathrm{AME} / \mathrm{kg}$ ) of the laying hen diets on egg quality from 17 to 46 wk of age.

\begin{tabular}{|c|c|c|c|c|c|c|c|c|c|c|}
\hline & \multirow[t]{2}{*}{ Dirty eggs(\%) } & \multirow[t]{2}{*}{ Broken(\%) } & \multirow[t]{2}{*}{ Shell-less(\%) } & \multirow[t]{2}{*}{ Haugh units } & \multicolumn{3}{|c|}{ Shell color ${ }^{\mathrm{a}}$} & \multirow[t]{2}{*}{ Yolk color $^{\mathrm{b}}$} & \multirow{2}{*}{$\begin{array}{l}\text { Shell strength } \\
\left(\mathrm{g} / \mathrm{cm}^{2}\right)\end{array}$} & \multirow{2}{*}{$\begin{array}{l}\text { Shell thickness } \\
(\mathrm{mm})\end{array}$} \\
\hline & & & & & $\mathrm{L}$ & $\mathrm{a}$ & $\mathrm{b}$ & & & \\
\hline \multicolumn{11}{|c|}{ Feed form, rearing phase } \\
\hline Mash & 1.47 & 0.51 & 0.22 & 92.1 & 61.2 & 15.5 & 32.1 & 10.3 & 4939 & 0.38 \\
\hline Crumbles & 1.29 & 0.46 & 0.18 & 92.0 & 61.2 & 15.5 & 32.1 & 10.2 & 4898 & 0.38 \\
\hline \multicolumn{11}{|c|}{ Energy level, rearing phase } \\
\hline $\mathrm{LE}^{\mathrm{c}}$ & 1.19 & 0.49 & 0.18 & 91.8 & 61.2 & 15.6 & 32.3 & 10.3 & 4992 & 0.38 \\
\hline $\mathrm{ME}^{\mathrm{d}}$ & 1.46 & 0.54 & 0.17 & 92.1 & 61.5 & 15.3 & 31.9 & 10.3 & 4846 & 0.38 \\
\hline $\mathrm{HE}^{\mathrm{e}}$ & 1.47 & 0.46 & 0.19 & 92.3 & 61.1 & 15.6 & 32.4 & 10.3 & 4916 & 0.38 \\
\hline \multicolumn{11}{|c|}{ Energy level, laying phase } \\
\hline Low $^{f}$ & 1.39 & 0.44 & 0.17 & 92.1 & 61.0 & 15.6 & 32.1 & 10.3 & 4915 & 0.38 \\
\hline High $^{g}$ & 1.36 & 0.52 & 0.23 & 91.9 & 61.4 & 15.4 & 32.1 & 10.3 & 4925 & 0.38 \\
\hline $\mathrm{SD}^{\mathrm{h}}$ & 0.528 & 0.109 & 0.028 & 0.93 & 0.86 & 0.90 & 0.52 & 0.41 & 216.2 & 0.007 \\
\hline \multicolumn{11}{|l|}{ P-value ${ }^{i}$} \\
\hline \multicolumn{11}{|l|}{ Rearing phase } \\
\hline Feed form & 0.272 & 0.414 & 0.347 & 0.833 & 0.896 & 0.695 & 0.590 & 0.322 & 0.560 & 0.543 \\
\hline Energy level & 0.193 & 0.291 & 0.100 & 0.158 & 0.249 & 0.265 & 0.124 & 0.793 & 0.170 & 0.399 \\
\hline \multicolumn{11}{|l|}{ Laying phase } \\
\hline Energy level & 0.876 & 0.175 & 0.144 & 0.629 & 0.112 & 0.151 & 0.688 & 0.794 & 0.867 & 0.320 \\
\hline
\end{tabular}

a Hunter color values, $\mathrm{L}^{*}$ (lightness), a* (green to red) and b* (blue to yellow).

b Measured with roche color fan.

c $11.93,11.30$ and $11.10 \mathrm{MJ} \mathrm{AME} / \mathrm{kg}$ from 0 to $5 \mathrm{wk}, 5$ to $10 \mathrm{wk}$ and 10 to $17 \mathrm{wk}$ of age, respectively.

d $12.35,11.72$ and $11.52 \mathrm{MJ} \mathrm{AME}_{\mathrm{n}} / \mathrm{kg}$ from 0 to $5 \mathrm{wk}, 5$ to $10 \mathrm{wk}$ and 10 to $17 \mathrm{wk}$ of age, respectively.

e $12.77,12.14$ and $11.94 \mathrm{MJ} \mathrm{AME}_{\mathrm{n}} / \mathrm{kg}$ from 0 to $5 \mathrm{wk}, 5$ to $10 \mathrm{wk}$ and 10 to $17 \mathrm{wk}$ of age, respectively.

f $11.10 \mathrm{MJ} \mathrm{AME} / \mathrm{kg}$.

g $11.52 \mathrm{MJ} \mathrm{AME}_{\mathrm{n}} / \mathrm{kg}$.

h 30 replicates for feed form in the rearing phase, 20 replicates for energy level in the rearing phase and 30 replicates for energy level in the laying phase.

i The interactions among main effects were not significant $(P>0.05)$.

Table 5

Effects of feed form and energy concentration of the rearing diets and energy concentration of the laying hen diet on the relative weight ( $\mathrm{g} / \mathrm{kg}$ BW) of the full gastrointestinal tract (GIT) of organs of the hens at $46 \mathrm{wk}$ of age.

\begin{tabular}{|c|c|c|c|c|c|c|c|c|}
\hline & \multirow[t]{2}{*}{$\mathrm{BW}(\mathrm{g})$} & \multirow{2}{*}{$\begin{array}{l}\text { GIT }(\mathrm{g} / \mathrm{kg} \\
\mathrm{BW})\end{array}$} & \multirow{2}{*}{$\begin{array}{l}\text { Liver }(\mathrm{g} / \mathrm{kg} \\
\text { BW) }\end{array}$} & \multirow{2}{*}{$\begin{array}{l}\text { Proventriculus } \\
(\mathrm{g} / \mathrm{kg} \mathrm{BW})\end{array}$} & \multicolumn{4}{|l|}{ Gizzard } \\
\hline & & & & & Full (g/kg BW) & Empty (g/kg BW) & $\begin{array}{l}\text { Content }(\mathrm{g} / \mathrm{kg} \\
\text { organ } \mathrm{W})\end{array}$ & $\mathrm{pH}$ \\
\hline \multicolumn{9}{|c|}{ Feed form, rearing phase } \\
\hline Mash & 1838 & 121 & 25.9 & 5.0 & 25.8 & 18.8 & 272 & 3.96 \\
\hline Crumbles & 1858 & 119 & 25.1 & 5.3 & 25.1 & 18.1 & 269 & 3.88 \\
\hline \multicolumn{9}{|c|}{ Energy level, rearing phase } \\
\hline $\mathrm{LE}^{\mathrm{c}}$ & 1850 & 120 & 25.2 & 4.9 & 25.5 & 18.3 & 273 & 3.85 \\
\hline $\mathrm{ME}^{\mathrm{d}}$ & 1844 & 120 & 25.8 & 5.4 & 25.4 & 18.7 & 274 & 3.91 \\
\hline $\mathrm{HE}^{\mathrm{e}}$ & 1838 & 121 & 25.5 & 5.1 & 25.4 & 18.6 & 267 & 4.01 \\
\hline \multicolumn{9}{|c|}{ Energy level, laying phase } \\
\hline Low $^{f}$ & 1849 & 120 & 25.7 & 5.1 & 25.6 & 18.3 & $281^{a}$ & 3.97 \\
\hline High $^{g}$ & 1848 & 120 & 25.3 & 5.1 & 25.3 & 18.7 & $261^{\mathrm{b}}$ & 3.88 \\
\hline $\mathrm{SD}^{\mathrm{h}}$ & 79.4 & 04.5 & 2.91 & 0.67 & 2.24 & 1.79 & 14.3 & 0.335 \\
\hline \multicolumn{9}{|l|}{ P-value ${ }^{i}$} \\
\hline \multicolumn{9}{|l|}{ Rearing phase } \\
\hline Feed form & & 0.234 & 0.307 & 0.157 & 0.995 & 0.885 & 0.780 & 0.429 \\
\hline Energy level & & 0.965 & 0.812 & 0.180 & 0.109 & 0.156 & 0.825 & 0.370 \\
\hline \multicolumn{9}{|l|}{ Laying phase } \\
\hline Energy level & & 0.545 & 0.636 & 0.962 & 0.724 & 0.313 & 0.026 & 0.311 \\
\hline
\end{tabular}

a Means with different superscript within each main effect are significantly different $(\mathrm{P}<0.05)$

b Means with different superscript within each main effect are significantly different $(\mathrm{P}<0.05)$.

c $11.93,11.30$ and $11.10 \mathrm{MJ} \mathrm{AME} / \mathrm{kg}$ from 0 to $5 \mathrm{wk}, 5$ to $10 \mathrm{wk}$ and 10 to $17 \mathrm{wk}$ of age, respectively.

d $12.35,11.72$ and $11.52 \mathrm{MJ} \mathrm{AME}_{\mathrm{n}} / \mathrm{kg}$ from 0 to $5 \mathrm{wk}, 5$ to $10 \mathrm{wk}$ and 10 to $17 \mathrm{wk}$ of age, respectively.

e $12.77,12.14$ and $11.94 \mathrm{MJ} \mathrm{AME} / \mathrm{kg}$ from 0 to $5 \mathrm{wk}, 5$ to $10 \mathrm{wk}$ and 10 to $17 \mathrm{wk}$ of age, respectively.

f $11.10 \mathrm{MJ} \mathrm{AME} / \mathrm{kg}$.

g $11.52 \mathrm{MJ} \mathrm{AME}_{\mathrm{n}} / \mathrm{kg}$.

h 30 replicates for feed form in the rearing phase, 20 replicates for energy level in the rearing phase and 30 replicates for energy level in the laying phase.

i The interactions among main effects were not significant $(P>0.05)$. 

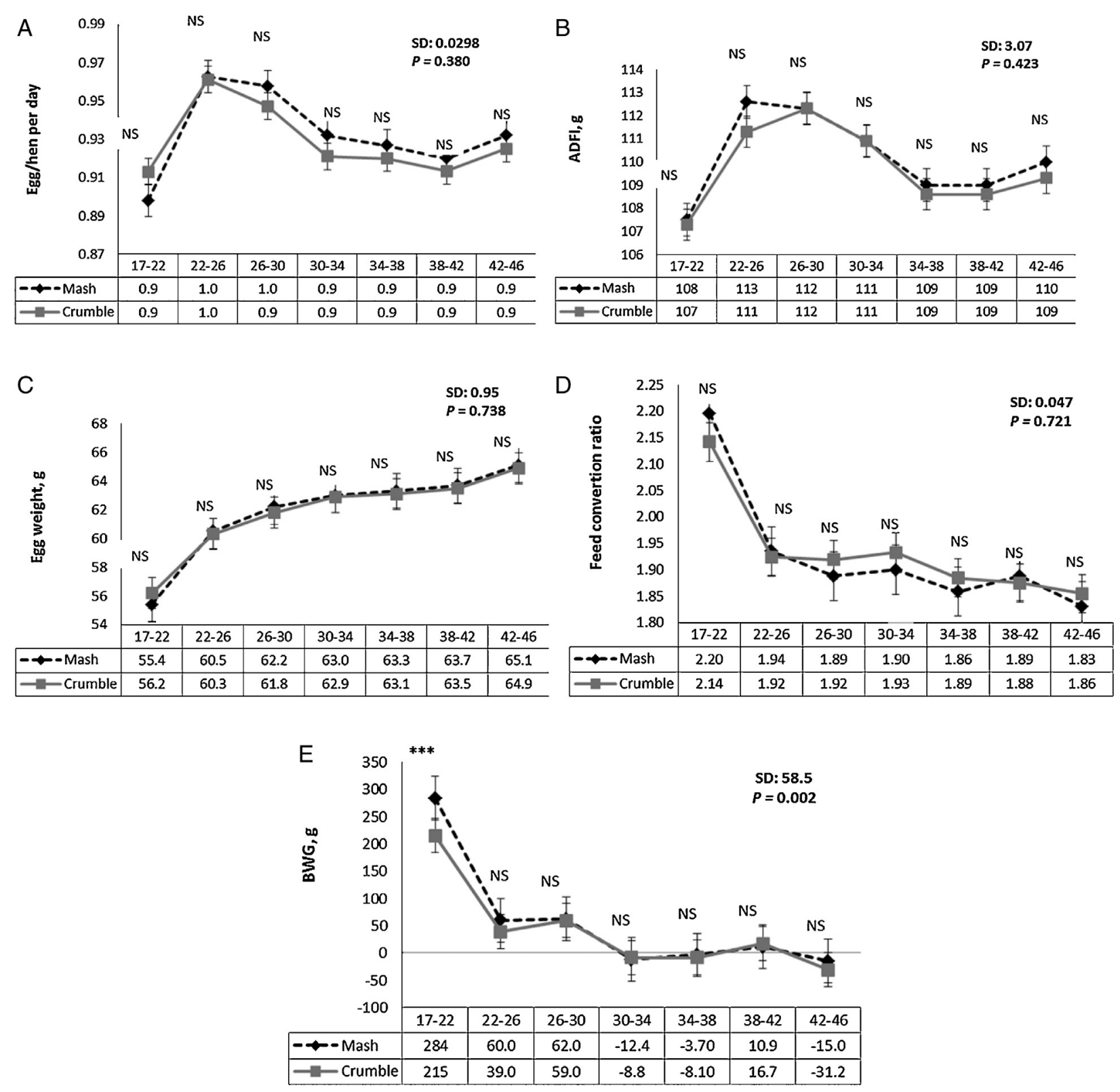

Fig. 1. Effect of feed form of the rearing diets on egg production (A), feed intake (B), egg weight (C), feed conversion ratio (D) and BW gain (BWG) (E) of the hens from 17 to $46 \mathrm{wk}$ of age.

${ }^{N S} \mathrm{P}>0.05 ;{ }^{* * *} \mathrm{P}<0.005$.

The effect of the period was significant $(\mathrm{P}<0.005)$ in all the variables studied.

no differences in egg production or egg weight among treatments were observed after this age. On the other hand, hens fed mash during the rearing phase were lighter at $17 \mathrm{wk}$ of age than hens fed crumbles but they gained weight more rapidly and in fact, no differences in BW were detected at $22 \mathrm{wk}$ of age. Consequently, the benefits of feeding crumbles to pullets on subsequent egg production might not be as relevant as expected and in most cases the potential benefits might be limited to the first few weeks of the laying period.

The authors have not found any published research on the effects of energy concentration of the pullet diets on subsequent hen performance. Usually, an increase in dietary energy results in heavier pullets that produce more egg mass and lay heavier eggs during the laying period (Pérez-Bonilla et al., 2012a). In the current research, BW at 17 wk of age was greater in pullets that were fed crumbles during the rearing phase than in pullets that were fed mash (1554 vs.1432 g) but after 22 wk of age, BW was not affected by the energy content of the rearing phase diets. The results reported herein indicate that a variation in the energy concentration of the rearing diets of $\pm 0.42 \mathrm{MJ} \mathrm{AME}_{\mathrm{n}} / \mathrm{kg}$ did not have any effect on subsequent hen performance. 

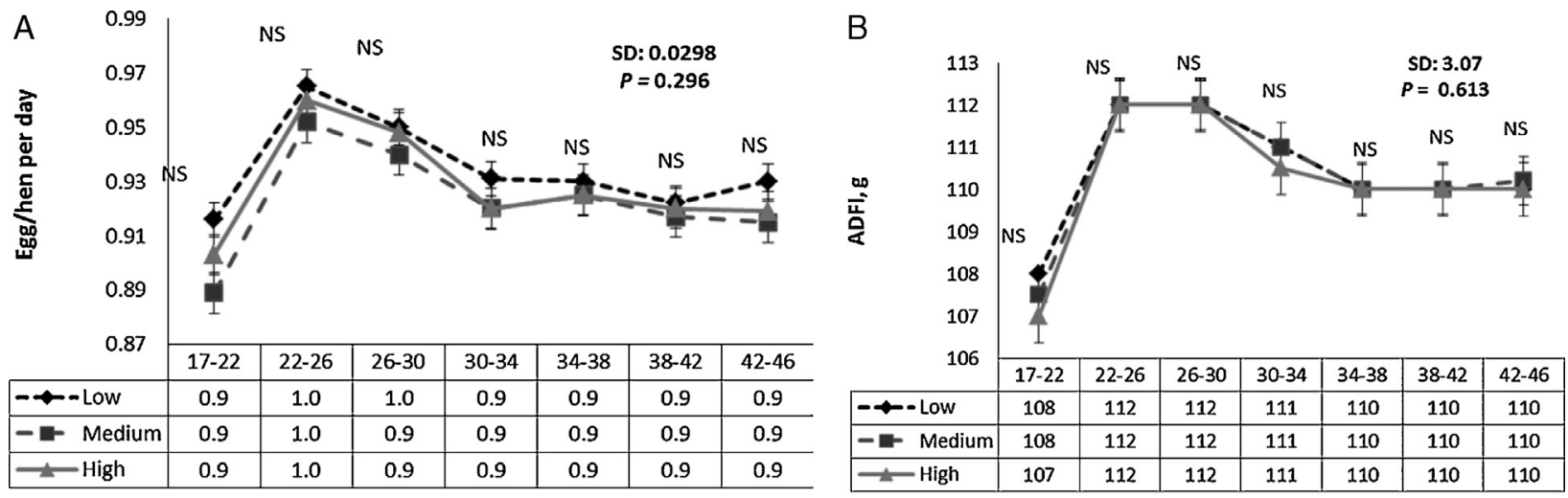

C
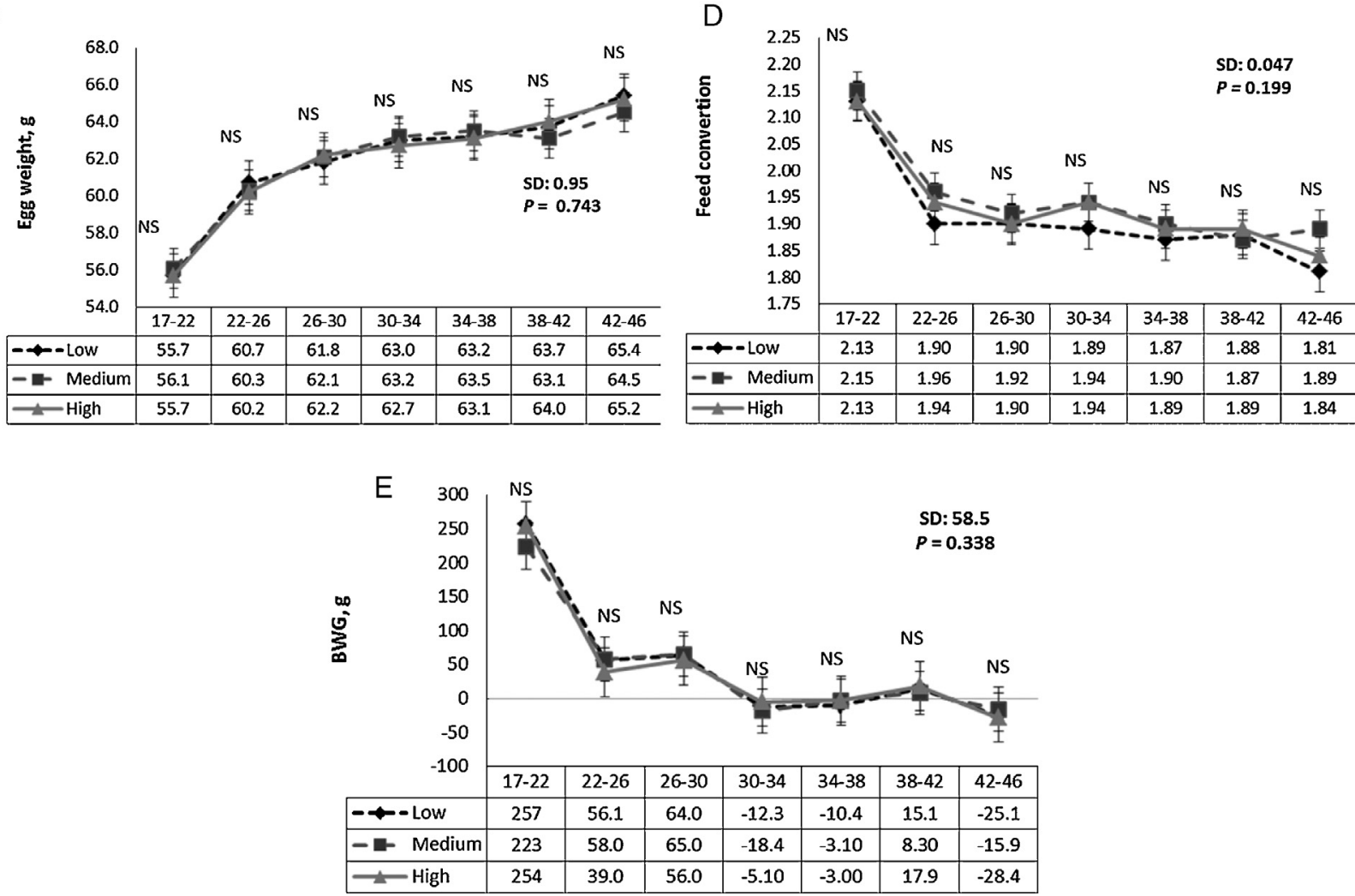

Fig. 2. Effect of energy content of the rearing diets ${ }^{\mathrm{a}}$ on egg production (A), feed intake (B), egg weight (C), feed conversion ratio (D) and BW gain (BWG) (E) of the hens from 17 to 46 wk of age.

a Low: $11.93,11.30$ and $11.10 \mathrm{MJ} \mathrm{AME} / \mathrm{kg}$ from 0 to $5 \mathrm{wk}, 5$ to $10 \mathrm{wk}$ and 10 to $17 \mathrm{wk}$ of age, respectively; medium: $12.35,11.72$ and $11.52 \mathrm{MJ}$ AME $/ \mathrm{kg}$ from 0 to $5 \mathrm{wk}, 5$ to $10 \mathrm{wk}$ and 10 to $17 \mathrm{wk}$ of age, respectively; high: $12.77,12.14$ and $11.94 \mathrm{MJ}$ AME $/ \mathrm{kg}$ from 0 to 5 wk, 5 to 10 wk and 10 to 17 wk of age, respectively.

NS $\mathrm{P}>0.05$.

The effect of the period was significant $(\mathrm{P}<0.005)$ in all the variables studied.

The data suggest that nutritionists might modify the energy level of the rearing phase diets, within the indicated limits, according to the relative prices of available ingredients.

\subsubsection{Laying phase diets}

From 17-46 wk of age, hens fed the high energy diet consumed 3.7\% less feed and had 3.1\% better FCR than hens fed the low energy diet but egg production was not affected, consistent with data of Grobas et al. (2001) and Safaa et al. (2009). The decrease in ADFI observed in hens fed the high energy diet was expected because poultry eat to satisfy their energy requirements, provided that the capacity of the GIT is not compromised (Hill et al., 1956; Leeson et al., 1997). Egg production and egg size were not affected by the energy content of the diet, consistent with data of Grobas et al. (1999b) in brown hens 

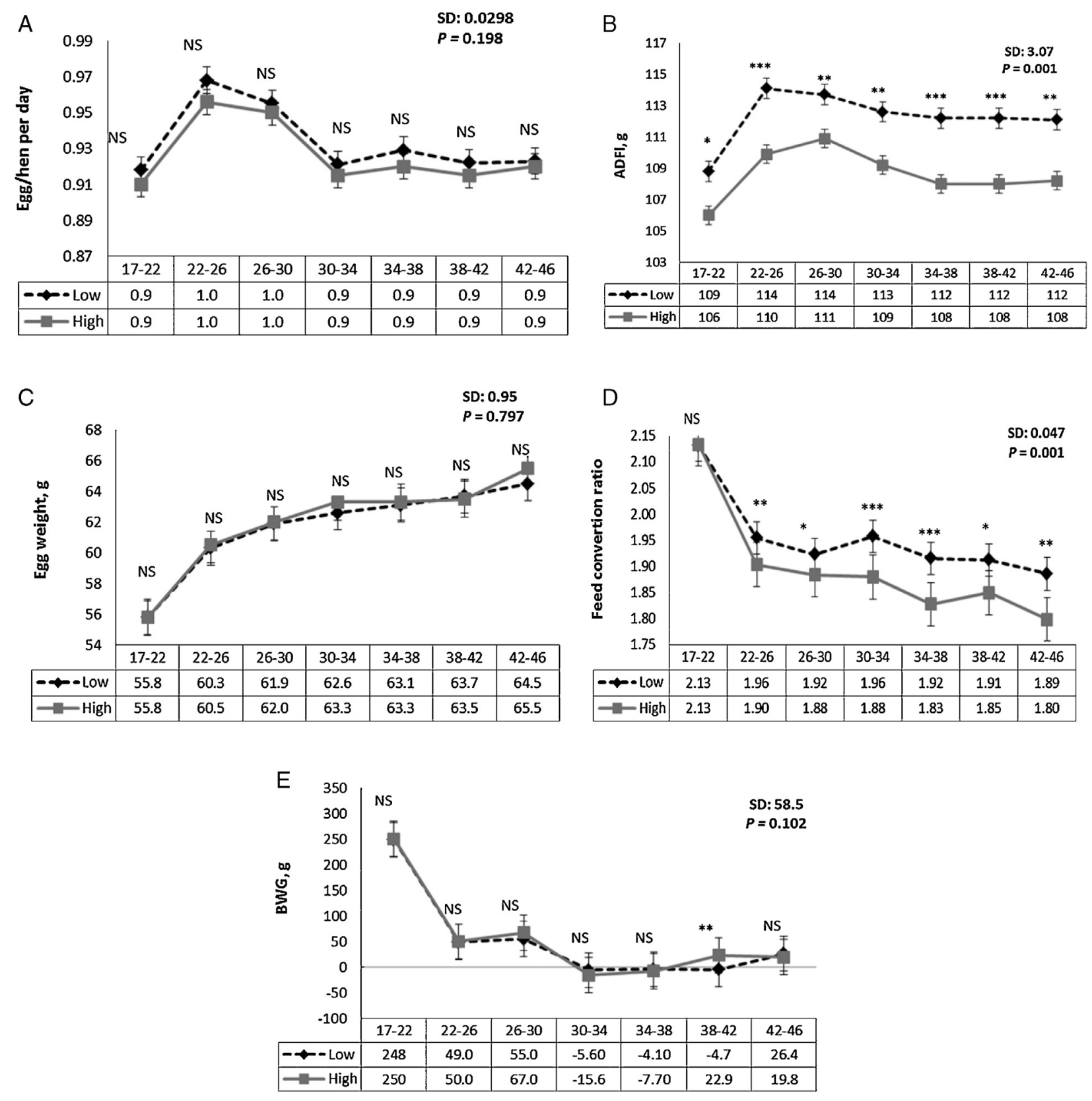

Fig. 3. Effect of energy concentration $\left(\mathrm{AME}_{\mathrm{n}} / \mathrm{kg}\right.$ ) on of the laying hen $\operatorname{diet}^{\mathrm{a}}$ on egg production (A), feed intake (B), egg weight (C), feed conversion ratio (D) and BW gain (BWG) (E) from 17 to $46 \mathrm{wk}$ of age.

${ }^{\text {a Low } 11.10 \mathrm{MJ} \mathrm{AME}} / \mathrm{kg} ;$ high: $11.52 \mathrm{MJ} \mathrm{AME}_{\mathrm{n}} / \mathrm{kg}$.

${ }^{N S} \mathrm{P}>0.05 ;{ }^{*} \mathrm{P}<0.05 ;{ }^{* *} \mathrm{P}<0.01 ;{ }^{* * *} \mathrm{P}<0.005$.

The effect of the period was significant $(\mathrm{P}<0.005)$ in all the variables studied.

fed diets varying in $\mathrm{AME}_{\mathrm{n}}$ from 11.22 to 11.76 MJ. In contrast, Mathlouthi et al. (2002) reported higher egg mass production in hens fed diets with $11.52 \mathrm{MJ} \mathrm{AME}_{\mathrm{n}} / \mathrm{kg}$ than in hens fed diets with $11.10 \mathrm{MJ} \mathrm{AME}_{\mathrm{n}} / \mathrm{kg}$. Similarly, Pérez-Bonilla et al. (2012a) reported higher egg production with increases in the $\mathrm{AME}_{\mathrm{n}}$ content of the diet from 11.10 to $11.94 \mathrm{MJ} / \mathrm{kg}$. The reason for the discrepancy among researches on the effects of energy concentration of the diet on egg production and egg mass, is not known but might be related to the strain of hens used as well as on the nutritional characteristics of the experimental diets. For example, in the experiment of Mathlouthi et al. (2002) Single Comb White Leghorrn hens were used and most of the difference in egg mass reported was caused by the lower weight of the eggs produced by hens fed the low energy diet (53.7 vs. $56.0 \mathrm{~g}$ ). The authors did not give any reason for the difference in egg size observed but the LNA content of the low and high energy diets used was 10.7 and $12.7 \mathrm{~g} / \mathrm{kg}$, respectively. The NRC (1994) recommended a minimum daily intake of $1.20 \mathrm{~g}$ LNA 
Table 6

Effects of feed form and energy concentration of the rearing diets and energy concentration $\left(\mathrm{AME} \mathrm{E}_{\mathrm{n}} / \mathrm{kg}\right)$ of the laying hen diet on the relative length ( $\mathrm{cm} / \mathrm{kg}$ $\mathrm{BW}^{\mathrm{a}}$ ) of the gastrointestinal tract at $46 \mathrm{wk}$ of age.

\begin{tabular}{|c|c|c|c|c|c|}
\hline & Duodenum & Jejunum & Ileum & $\mathrm{SI}^{\mathrm{b}}$ & Cecum \\
\hline \multicolumn{6}{|c|}{ Feed form, rearing phase } \\
\hline Mash & 14.0 & 41.8 & 38.4 & 94.2 & 24.4 \\
\hline Crumbles & 13.8 & 42.0 & 37.8 & 93.6 & 23.8 \\
\hline \multicolumn{6}{|c|}{ Energy level, rearing phase } \\
\hline $\mathrm{LE}^{\mathrm{c}}$ & 13.7 & 41.1 & 38.0 & 92.7 & 23.5 \\
\hline $\mathrm{ME}^{\mathrm{d}}$ & 14.5 & 42.8 & 38.5 & 95.8 & 24.5 \\
\hline $\mathrm{HE}^{\mathrm{e}}$ & 13.7 & 41.7 & 37.9 & 93.3 & 24.3 \\
\hline \multicolumn{6}{|c|}{ Energy level, laying phase } \\
\hline Low $^{\mathrm{f}}$ & 14.1 & 41.8 & 37.8 & 93.7 & 23.8 \\
\hline High $^{g}$ & 13.8 & 42.0 & 38.4 & 94.2 & 24.4 \\
\hline $\mathrm{SD}^{\mathrm{h}}$ & 1.79 & 3.42 & 2.68 & 6.69 & 2.91 \\
\hline \multicolumn{6}{|l|}{ P-value ${ }^{\mathrm{i}}$} \\
\hline \multicolumn{6}{|l|}{ Rearing phase } \\
\hline Feed form & 0.654 & 0.822 & 0.405 & 0.729 & 0.408 \\
\hline Energy level & 0.201 & 0.285 & 0.734 & 0.290 & 0.530 \\
\hline \multicolumn{6}{|l|}{ Laying phase } \\
\hline Energy level & 0.489 & 0.810 & 0.399 & 0.776 & 0.455 \\
\hline
\end{tabular}

a The BW of the hens is shown in Table 5.

b Small intestine (duodenum, jejunum and ileum).

c $11.93,11.30$ and $11.10 \mathrm{MJ} \mathrm{AME} / \mathrm{kg}$ from 0 to $5 \mathrm{wk}, 5$ to $10 \mathrm{wk}$ and 10 to $17 \mathrm{wk}$ of age, respectively.

d $12.35,11.72$ and $11.52 \mathrm{MJ} \mathrm{AME}_{\mathrm{n}} / \mathrm{kg}$ from 0 to $5 \mathrm{wk}, 5$ to $10 \mathrm{wk}$ and 10 to $17 \mathrm{wk}$ of age, respectively.

e $12.77,12.14$ and $11.94 \mathrm{MJ} \mathrm{AME}_{\mathrm{n}} / \mathrm{kg}$ from 0 to $5 \mathrm{wk}, 5$ to $0 \mathrm{wk}$ and 10 to $17 \mathrm{wk}$ of age, respectively.

f $11.10 \mathrm{MJ} \mathrm{AME} / \mathrm{kg}$.

g $11.52 \mathrm{MJ} \mathrm{AME}_{\mathrm{n}} / \mathrm{kg}$.

$\mathrm{h} 30$ replicates for feed form in the rearing phase, 20 replicates for energy level in the rearing phase and 30 replicates for energy level in the laying phase.

$\mathrm{i}$ The interactions among main effects were not significant $(P>0.05)$.

Table 7

Effects of feed form and energy content of the rearing diets and energy concentration ( $\mathrm{AME}_{\mathrm{n}} / \mathrm{kg}$ ) of the laying hen diet on body measurements at 46 wk of age.

\begin{tabular}{|c|c|c|c|c|}
\hline & \multirow[t]{2}{*}{ Hen length $\left(\mathrm{cm} / \mathrm{BW}^{\mathrm{a}}\right)$} & \multirow[t]{2}{*}{$\mathrm{BMI}^{\mathrm{b}}\left(\mathrm{g} / \mathrm{cm}^{2}\right)$} & \multicolumn{2}{|c|}{ Tarsus (cm/BW) } \\
\hline & & & Length & Diameter \\
\hline \multicolumn{5}{|c|}{ Feed form, rearing phase } \\
\hline Mash & 36.0 & 0.43 & 5.54 & 0.71 \\
\hline Crumbles & 35.6 & 0.44 & 5.46 & 0.72 \\
\hline \multicolumn{5}{|c|}{ Energy level, rearing phase } \\
\hline $\mathrm{LE}^{\mathrm{C}}$ & 35.7 & 0.45 & 5.46 & 0.71 \\
\hline $\mathrm{ME}^{\mathrm{d}}$ & 35.8 & 0.43 & 5.46 & 0.71 \\
\hline $\mathrm{HE}^{\mathrm{e}}$ & 36.0 & 0.43 & 5.57 & 0.72 \\
\hline \multicolumn{5}{|c|}{ Energy level, laying phase } \\
\hline Low $^{\mathrm{f}}$ & 35.8 & 0.44 & 5.53 & 0.71 \\
\hline High $^{g}$ & 35.8 & 0.43 & 5.47 & 0.72 \\
\hline $\mathrm{SD}^{\mathrm{h}}$ & 1.68 & 0.022 & 0.291 & 0.022 \\
\hline \multicolumn{5}{|l|}{ P-value ${ }^{i}$} \\
\hline \multicolumn{5}{|l|}{ Rearing phase } \\
\hline Feed form & 0.347 & 0.193 & 0.353 & 0.339 \\
\hline Energy level & 0.822 & 0.928 & 0.361 & 0.301 \\
\hline \multicolumn{5}{|l|}{ Laying phase } \\
\hline Energy level & 0.976 & 0.384 & 0.360 & 0.309 \\
\hline
\end{tabular}

a The BW of the hens is shown in Table 5.

b Body mass index.

c $11.93,11.30$ and $11.10 \mathrm{MJ} \mathrm{AME}_{\mathrm{n}} / \mathrm{kg}$ from 0 to $5 \mathrm{wk}, 5$ to $10 \mathrm{wk}$ and 10 to $17 \mathrm{wk}$ of age, respectively.

d $12.35,11.72$ and $11.52 \mathrm{MJ} \mathrm{AME} / \mathrm{kg}$ from 0 to $5 \mathrm{wk}, 5$ to $10 \mathrm{wk}$ and 10 to $17 \mathrm{wk}$ of age, respectively.

e $12.77,12.14$ and $11.94 \mathrm{MJ} \mathrm{AME}_{\mathrm{n}} / \mathrm{kg}$ from 0 to $5 \mathrm{wk}, 5$ to $10 \mathrm{wk}$ and 10 to $17 \mathrm{wk}$ of age, respectively.

f $11.10 \mathrm{MJ} \mathrm{AME}_{\mathrm{n}} / \mathrm{kg}$.

g $11.52 \mathrm{MJ} \mathrm{AME} / \mathrm{kg}$.

h 30 replicates for feed form in the rearing phase, 20 replicates for energy level in the rearing phase and 30 replicates for energy level in the laying phase.

$i$ The interactions among main effects were not significant $(P>0.05)$.

per day to maximize egg size in brown-egg laying hens. Probably, the low LNA intake was limiting egg mass production in hens fed the low energy diet, penalizing feed efficiency. In contrast, in the current research LNA intake was 2.94 and $2.15 \mathrm{~g} / \mathrm{d}$ for the high and low energy diets, respectively, values that were above requirements for both groups of hens (Grobas et al., 2001; Bouvarel et al., 2010). Also, in the research of Pérez-Bonilla et al. (2012a), in which egg production increased with increases in the energy content of the diet, an increase in energy concentration of $7.5 \%(11.10-11.94 \mathrm{MJ} \mathrm{AME} / \mathrm{kg}$ ) decreased 
Correlations between full BW ${ }^{\mathrm{a}}$ and body length, tarsus length and diameter and body mass index (BMI) of the hens at 46 wk of age.

\begin{tabular}{|c|c|c|c|c|}
\hline & \multicolumn{4}{|l|}{ BW } \\
\hline & \multirow[t]{2}{*}{ Body length (cm) } & \multirow[t]{2}{*}{$\mathrm{BMI}\left(\mathrm{g} / \mathrm{cm}^{2}\right)$} & \multicolumn{2}{|c|}{ Tarsus(cm) } \\
\hline & & & Length & $\overline{\text { Diameter }}$ \\
\hline $\mathrm{R}$ & 0.394 & 0.637 & 0.414 & 0.351 \\
\hline P-value & $<0.001$ & $<0.001$ & $<0.001$ & $<0.001$ \\
\hline
\end{tabular}

a The BW of the hens is shown in Table 5.

b Body length, BMI and tarsus length and diameter of the hens are shown in Table 7.

ADFI by 3.5\%, which resulted in a 3.9\% increase in energy intake and in a subsequent improvement in egg production. In the current experiment, however, an increase of $0.42 \mathrm{MJ} \mathrm{AME}_{\mathrm{n}} / \mathrm{kg}$ diet (a 3.8\% increase) resulted in a similar increase in energy intake and consequently, no changes in hen performance between the two groups of hens were expected.

An increase in dietary energy is generally attained by increasing the amount of supplemental fat. Mateos and Sell (1980, 1981 ) showed that supplemental fat reduced the rate of passage of the digesta, facilitating the contact between nutrients and enzymes and improving the utilization of the non-fiber components of the diet. Moreover, when the lipid content of the diet increases, the level of LNA content also increases. Both effects, reduced rate of passage and increased LNA content, might result in an increase in egg size and an improvement in FCR (Grobas et al., 1999c). In the current experiment, the low and high energy diets contained 54 and $68 \mathrm{~g} / \mathrm{kg}$ ether extract and 19 and $27 \mathrm{~g} / \mathrm{kg}$ LNA, respectively. Probably, the small difference in ether extract content of the 2 diets did not result in any visible effect on egg weight. On the other hand, the LNA content of the low energy diet $(19 \mathrm{~g} / \mathrm{kg}$ ) met already the requirement of the hens to maximize egg weight (Grobas et al., 1999a; Safaa et al., 2009). The data suggest that laying hens, in the range of energy concentration studied (11.10-11.52 MJ $\mathrm{AME}_{\mathrm{n}} / \mathrm{kg}$ ), and provided that the requirements in other essential nutrients (indispensable amino acids, LNA and fat content) are satisfied, regulate ADFI precisely according to energy requirements.

\subsection{Egg quality}

Egg quality was not affected by feed form of the rearing phase diets or by the energy concentration of the rearing and laying phase diets. The authors have not found any published research on the effects of the characteristics of the rearing diets on egg quality to compare with the results reported herein. In regard to dietary energy, Grobas et al. (1999b) and Pérez-Bonilla et al. (2012a) observed similar egg quality (dirty, broken, shell-less, Haugh units, yolk pigmentation and yolk to albumen ratio) for hens fed diets containing 11.10 or $11.52 \mathrm{MJ} \mathrm{AME} / \mathrm{kg}$, in agreement with the results reported herein. However, Zimmermann and Andrews (1987) and Wu et al. (2005) observed a reduction in albumen quality and Junqueira et al. (2006) a decrease in the percentage of shell-less eggs with increases in the energy concentration of the diet. Factors such as strain and age of the hens, as well as the ingredient composition of the diet, might affect the response of egg quality traits to variations in energy content of the diet. For example, Zimmermann and Andrews (1987) and Junqueira et al. (2006) used Leghorn hens in the second cycle of egg production and Wu et al. (2005) reported that the decrease in $A_{M} E_{n}$ of the diet reduced yolk size, which in turn could affect egg size and other egg quality traits.

\subsection{Digestive traits and body measurements}

The interest on the effects of the ingredient composition and physico-chemical characteristics of the diets on the anatomy and physiology of the GIT in poultry has increased in the last decade but most available data have been obtained in broilers (Mateos et al., 2002, 2012; Serrano et al., 2012; Jiménez-Moreno et al., 2016) and pullets (Saldaña et al., 2015a), with little information in laying hens. In fact, we have not found any published report on the effects of feed form and energy content of the rearing phase diets on digestive tract traits of the hens at the end of the laying period. In the current research, neither feed form nor energy content of the rearing phase diets affected the development and function of the different organs of the GIT of the hens at $46 \mathrm{wk}$ of age. Moreover, the energy content of the layer diet had little effect on the development of the GIT at this age. In fact, the only difference observed was for gizzard digesta content that was greater in hens fed the low energy diet. In this respect, feed intake was higher in hens fed the low energy diet than in hens fed the high energy diets and consequently, an increase in the digesta content of the gizzard was expected. In addition, fiber content was higher in the low- than in the high energy diet, which may result in an increase in digesta content, as has been demonstrated in broilers by González-Alvarado et al. (2008). The results show that feed form and energy concentration of the rearing phase diets and energy concentration of the laying phase diets, had little effect on subsequent hen performance or on the characteristics of the digestive tract at the end of the laying cycle.

Body length, BMI and tarsus measurements are used to evaluate body composition and size and to predict future performance of broilers (Mendes et al., 2007; Van Roovert-Reijrink, 2013), pullets (Itza et al., 2011; Guzmán et al., 2015b) and laying hens (Ojedapo et al., 2012; Guzmán et al., 2016). Body length, BMI and length and diameter of the tarsus were not affected by dietary treatment, indicating that neither the characteristics of the rearing phase diets nor the energy content 
of the laying phase diets affected body size of the mature hens. However, a significant relationship between BW of the hens and body length, BMI and tarsus length and diameter was detected, consistent with the results of Guzmán et al. (2015b).

\section{Conclusions}

Feed form and energy concentration of the rearing phase diets had little effect on the performance and egg quality of the hens during the entire laying cycle or on GIT traits and morphometric measurements of the hens at 46 wk of age. An increase in the energy content of the laying phase diets from 11.10 to $11.52 \mathrm{MJ} / \mathrm{kg}$ decreased ADFI and improved FCR proportionally to the increase in energy concentration but did not affect any of the other traits studied. Consequently, nutritionists may adapt the characteristics of the rearing and laying phase diets, within the range of values studied, to the cost of available ingredients, without any detectable effect on hen productivity or egg quality.

\section{Conflict of interest statement}

The authors confirm they are not conflict of interest in this research.

\section{Acknowledgements}

This research was supported through project AGL 2014-56139, Ministerio de Economía y Competitividad, Madrid, Spain.

\section{References}

AOAC International, 2005. Official Methods of Analysis of the AOAC International, 18th ed. AOAC Int., Gaithersburg, MD.

ASAE, 1995. Standard S319.2: Method of determining and expressing fineness of feed material by sieving. Pages 461-462 in Agriculture Engineers Yearbook of Standards. Amer. Soc. Agric. Eng., St. Joseph, MO.

Boletín Oficial del Estado, 1995. Real Decreto 2257/1994 por el que se aprueba los mítodos oficiales de anélisis de piensos o alimentos para animales y sus primeras materias. BOE 52, 7161-7237.

Boletín Oficial del Estado, 2007. Ley 32/2007 de 7 de Noviembre para el cuidado de los animales, en su explotaciín, transporte, experimentaciín y sacrificio. BOE 268, 45914-45920.

Bouvarel, I., Nys, Y., Panheleux, M., Lescoat, P., 2010. Comment l'alimentation des poules influence la qualité des oeufs. INRA Prod. Anim. $23,167-182$.

De Coca-Sinova, A.D., Valencia, G., Jiménez-Moreno, E., González-Alvarado, J.M., Lázaro, R., Mateos, G.G., 2008. Apparent ileal digestibility of nitrogen, amino acids, and energy of soybean meals from different origins in broilers. Poult. Sci. 87, 2613-2623.

FEDNA (Fundación Española Desarrollo Nutrición Animal), 2010. Normas FEDNA para la Formulación de Piensos Compuestos. 3rd ed. In: De Blas, C., G.G. Mateos, P.G. Rebollar (Eds). Fund. Esp. Desarro. Nutr. Anim., Madrid, Spain.

Frikha, M., Safaa, H.M., Serrano, M.P., Arbe, X., Mateos, G.G., 2009a. Influence of the main cereal and feed form of the diet on performance and digestive tract traits of brown-egg laying pullets. Poult. Sci. 88, 994-1002.

Frikha, M., Safaa, H.M., Jiménez-Moreno, E., Lázaro, R., Mateos, G.G., 2009b. Influence of energy concentration and feed form of the diet on growth performance and digestive traits of brown egg-laying pullets from 1 to 120 days of age. Anim. Feed Sci. Technol. 153, $292-302$.

González-Alvarado, J.M., Jiménez-Moreno, E., González-Sánchez, D., Lázaro, R., Mateos, G.G., 2007. Effect of type of cereal, heat processing of the cereal, and inclusion of fiber in the diet on productive performance and digestive traits of broilers. Poult. Sci. 86, $1705-1715$.

González-Alvarado, J.M., Jiménez-Moreno, E., Valencia, D.G., Lázaro, R., Mateos, G.G., 2008. Effects of fiber source and heat processing of the cereal on the development and $\mathrm{pH}$ of the gastrointestinal tract of broilers fed diets based on corn or rice. Poult. Sci. 87, 1779-1795.

Gous, R.M., Morris, T.R., 2001. The influence of pelleted feed on the response of growing pullets to photoperiods of less than ten hours. Br. Poult. Sci. 42, 203-206.

Grobas, S., Mateos, G.G., Méndez, J., 1999a. Influence of dietary linoleic acid on production and weight of eggs and egg components in young brown hens J. Appl. Poult. Res. 8, 177-184

Grobas, S., Méndez, J., De Blas, C., Mateos, G.G., 1999b. Laying hen productivity as affected by energy, supplemental fat, and linoleic acid concentration of the diet. Poult. Sci. 78, 1542-1551.

Grobas, S., Méndez, J., De Blas, C., Mateos, G.G., 1999c. Influence of dietary energy, supplemental fat and linoleic acid concentration on performance of laying hens at two ages. Br. Poult. Sci. 40, 681-687.

Grobas, S., Méndez, J., De Blas, C., Mateos, G.G., 2001. Influence of source and percentage of fat added to diet on performance and fatty acid composition of egg yolks of two strains of laying hens. Poult. Sci. 80, 1171-1179.

Guzmán, P., Saldaña, B., Mandalawi, H.A., Pérez-Bonilla, A., Lázaro, R., Mateos, G.G., 2015a. Productive performance of brown-egg laying pullets from hatching to 5 weeks of age as affected by fiber inclusion, feed form, and energy concentration of the diet. Poult. Sci. 94, $249-261$.

Guzmán, P., Saldaña, B., Kimiaeitalab, M.V., García, J., Mateos, G.G., 2015b. Inclusion of fiber in diets for brown-egg laying pullets: effects on growth performance and digestive tract traits from hatching to 17 weeks of age. Poult. Sci. 94, 2722-2733.

Guzmán, P., Saldaña, B., Bouali, O., Cámara, L., Mateos, G.G., 2016. Effect of level of fiber of the rearing phase diets on egg production, digestive tract traits, and body measurements of brown egg-laying hens fed diets differing in energy concentration. Poult. Sci. 95, 1836-1847.

Hill, F.W., Anderson, D.L., Dansky, L.M., 1956. Studies of the energy requirements of chickens 3: The effect of dietary energy level on the rate and gross efficiency of egg production. Poult. Sci. 35, 54-59.

Itza, M.F., Ortiz, J., Janacua, H., Olguien, H.A., Quintero, J.A., Rodríguez, C.A., Martín, U., 2011. Growth characteristics of pullets based on type of housing. Pesq. Agropec. Bras. 46, 768-771.

Jiménez-Moreno, E., González-Alvarado, J.M., De Coca-Sinova, A., Lázaro, R., Mateos, G.G., 2009a. Effects of source of fiber on the development and pH of the gastrointestinal tract of broilers. Anim. Feed Sci. Technol. 154, 93-101.

Jiménez-Moreno, E., González-Alvarado, J.M., De Coca-Sinova, A., Lázaro, R., Mateos, G.G., 2009b. Effects of source of fibre on the development and pH of the gastrointestinal tract of broilers. Anim. Feed Sci. Technol. 154, 93-101.

Jiménez-Moreno, E., De Coca-Sinova, A., González-Alvarado, J.M., Mateos, G.G., 2016. Inclusion of insoluble fiber sources in mash or pellet diets for young broilers: 1. Effects on growth performance and water intake. Poult. Sci 95, 41-52.

Junqueira, O.M., De Laurentiz, A.C., Da Silva Filardi, R., Rodrigues, E.A., Casartelli, E.M., 2006. Effects of energy and protein levels on egg quality and performance of laying hens at early second production cycle. J. Appl. Poult. Res. 15, 110-115.

Leeson, S., Caston, L., Summers, J.D., 1997. Layer performance of four strains of leghorn pullets subjected to various rearing programs. Poult. Sci. 76, 1-5.

Mateos, G.G., Sell, J.L., 1980. Influence of carbohydrate and supplemental fat source on the metabolizable energy of the diet. Poult. Sci. 59, $2129-2135$.

Mateos, G.G., Sell, J.L., 1981. Nature of the extrametabolic effect of supplemental fat used in semipurified diets for laying hens. Poult. Sci. 60, $1925-1930$. 
Mateos, G.G., Lázaro, R., Gracia, M.I., 2002. The feasibility of using nutritional modifications to replace drugs in poultry feeds. J. Appl. Poult. Res. 11, 437-452.

Mateos, G.G., Jiménez-Moreno, E., Serrano, M.P., Lázaro, R.P., 2012. Poultry response to high levels of dietary fiber sources varying in physical and chemical characteristics. J. Appl. Poult. Res. 21, 156-174.

Mathlouthi, N., Larbier, M., Mohamed, M.A., Lessire, M., 2002. Performance of laying hens fed wheat, wheat-barley or wheat-barley-wheat bran based diets supplemented with xylanase. Can. J. Anim. Sci. 82, 193-199.

Mendes, M., Ecmel, D., Arslan, E., 2007. Profile analysis and growth curve for body mass index of broiler chickens reared under different feed restrictions in early age. Arch. Tierz. 50, 403-411.

NRC, 1994. Nutrient Requirements of Poultry, 9th rev. ed. Natl. Acad. Press, Washington, DC.

Nir, I., Twina, Y., Grossman, E., Nitsan, Z., 1994. Quantitative effects of pelleting on performance, gastrointestinal tract and behavior of meat-type chickens. Br. Poult. Sci. 35, 589-602.

Ojedapo, L.O., Amao, S.R., Ameen, S.A., Adedeji, T.A., Ogundipe, R.I., Ige, A.O., 2012. Prediction of body weight and other linear body measurement of two commercial layer strain chickens. Asian J. Anim. Sci. 6, 13-22.

Pérez-Bonilla, A., Novoa, S., García, J., Mohiti-Asli, M., Frikha, M., Mateos, G.G., 2012a. Effects of energy concentration of the diet on productive performance and egg quality of brown egg-laying hens differing in initial body weight. Poult. Sci. 91, 3156-3166.

Pérez-Bonilla, A., Jabbour, S.C., Frikha, M., Mirzaie, S., García, J., Mateos, G.G., 2012b. Effect of crude protein and fat content of diet on productive performance and egg quality traits of brown egg-laying hens with different initial body weight. Poult. Sci. 91, $1400-1405$.

Renema, R.A., Robinson, F.E., Proudman, J.A., Newcombe, M., McKay, R.I., 1999a. Effects of body weight and feed allocation during sexual maturation in broiler breeder hens: 2. Ovarian morphology and plasma hormone profiles. Poult. Sci. 78, 629-639.

Renema, R.A., Robinson, F.E., Newcombe, M., McKay, R.I., 1999b. Effects of body weight and feed allocation during sexual maturation in broiler breeder hens: 1. Growth and carcass characteristics. Poult. Sci. 78, 619-628.

SAS Institute, 2004. SAS/STAT User's Guide Version 9.1. SAS Inst. Inc., Cary, NC.

Sacranie, A., Svihus, B., Denstadli, V., Moen, B., Iji, P.A., Choct, M., 2012. The effect of insoluble fiber and intermittent feeding on gizzard development gut motility, and performance of broiler chickens. Poult. Sci. 91, 693-700.

Safaa, H.M., Serrano, M.P., Valencia, D.G., Frikha, M., Jiménez-Moreno, E., Mateos, G.G., 2008. Productive performance and egg quality of brown egg-laying hens in the late phase of production as influenced by level and source of calcium in the diet. Poult. Sci. 87, 2043-2051.

Safaa, H.M., Jiménez-Moreno, E., Valencia, D.G., Frikha, M., Serrano, M.P., Mateos, G.G., 2009. Effect of main cereal of the diet and particle size of the cereal on productive performance and egg quality of brown egg-laying hens in early phase of production. Poult. Sci. 88, 608-614.

Saldaña, B., Guzmán, P., Safaa, H.M., Harzalli, R., Mateos, G.G., 2015a. Influence of the main cereal and feed form of the diet on performance and digestive tract and body traits of brown-egg laying pullets from hatch to 17 weeks of age. Poult. Sci. 94, 2650-2651.

Saldaña, B., Guzmán, P., Cámara, L., García, J., Mateos, G.G., 2015b. Feed form and energy concentration of the diet affect productive performance and digestive tract traits of brown-egg laying pullets from hatching to 17 weeks of age. Poult. Sci. 94, 1879-1893.

Serrano, M.P., Valencia, D.G., Méndez, J., Mateos, G.G., 2012. Influence of feed form and source of soybean meal of the diet on growth performance of broilers from 1 to 42 days of age.1. Floor pen study. Poult. Sci 91, 2838-2844.

Serrano, M.P., Frikha, M., Corchero, J., Mateos, G.G., 2013. Influence of feed form and source of soybean meal on growth performance nutrient retention, and digestive organ size of broilers. 2. Battery study. Poult. Sci. 92, 693-708.

Summers, J.D., Leeson, S., Spratt, D., 1987. Rearing early maturing pullets. Poult. Sci. 66, 1750-1757.

Van Roovert-Reijrink, I., 2013. Incubation affects chick quality. World's Poult. Sci. 29, 22-23.

Wu, G., Bryant, M.M., Voitle, R.A., Roland Sr, D.A., 2005. Effect of dietary energy on performance and egg composition of Bovans white and Dekalb white hens during phase I. Poult. Sci. 84, 1610-1615.

Zimmermann, N.G., Andrews, D.K., 1987. Comparison of several induced molting methods on subsequent performance of single comb White Leghorn hens. Poult. Sci. 66, 408-417. 